\title{
Temperature explains the yield difference of double-season rice between tropical and subtropical environments
}

Depeng Wang ${ }^{\mathrm{a}}$, Ma. Rebecca C. Laza ${ }^{\mathrm{b}}$, Kenneth G. Cassman ${ }^{\mathrm{c}}$, Jianliang Huang ${ }^{\mathrm{a}}$, Lixiao Nie $^{\mathrm{a}}$, Xiaoxia Ling ${ }^{\mathrm{a}}$, Grace S. Centeno ${ }^{\mathrm{b}}$, Kehui Cui ${ }^{\mathrm{a}}$, Fei Wang ${ }^{\mathrm{a}}$, Yong Li ${ }^{\mathrm{a}}$, Shaobing Peng $^{\mathrm{a}}$ *

${ }^{a}$ National Key Laboratory of Crop Genetic Improvement, MOA Key Laboratory of Crop Ecophysiology and Farming System in the Middle Reaches of the Yangtze River, College of Plant Science and Technology, Huazhong Agricultural University, Wuhan, Hubei 430070, China.

${ }^{\mathrm{b}}$ Crop and Environmental Sciences Division, International Rice Research Institute, DAPO Box 7777, Metro Manila, Philippines.

${ }^{c}$ Department of Agronomy and Horticulture, University of Nebraska-Lincoln, PO Box 830915, Lincoln, Nebraska 68583-0915, USA.

*Corresponding author. Tel.:+86 278728 8668; Fax: +86 2787288380

E-mail: speng@mail.hzau.edu.cn (S. Peng)

Received: ; accepted:

Journal for submission: Field Crops Research 


\begin{abstract}
Crop yields are largely influenced by air temperature and solar radiation, but the individual effects of these weather variables are difficult to distinguish because they are often not independent. Here, we demonstrate a large effect of temperature on rice grain yield when solar radiation and crop growth duration were not confounding factors for explaining yield difference across two locations in the tropical and subtropical environments. We found that grain yield of double-season rice crops in the subtropical environment of Wuxue County, Hubei Province, China was 9-66\% higher than that in the tropical environment of International Rice Research Institute (IRRI), Philippines. Such yield difference was not caused by the difference in crop growth duration from transplanting to maturity. Biomass production rather than harvest index was responsible for the yield difference. Average daily minimum and maximum temperature from transplanting to maturity at IRRI was 3.4 and $1.9^{\circ} \mathrm{C}$ higher than that at Wuxue, respectively, whereas average daily solar radiation at Wuxue was lower or similar to that at IRRI. Crop's efficiency in converting solar radiation into biomass (i.e. radiation use efficiency, RUE) at Wuxue was $48 \%$ higher than that at IRRI, which was associated with the difference in temperature between the two environments. We concluded that lower rice yield in the tropical environment was associated with lower RUE, which was due to the higher temperature compared with the subtropical environment. Our results suggested the crop adaptation strategies for global climate changes should focus more on future warming.
\end{abstract}

Keywords: Double-season rice; grain yield; radiation use efficiency; temperature; tropics and subtropics. 


\section{Introduction}

The world is facing potential food shortages due to the growing population and the threat of climate change on crop productivity (Long et al., 2015). Rice is the staple food for more than half of the world's population (Maclean et al., 2002). World rice production has nearly tripled in the past five decades mainly due to increased grain yield and partly due to increased planting area (FAO, 2015). However, the arable land used for rice production is reducing because of urbanization and industrialization in the major rice producing regions (Long, 2014). Future increase in rice production will have to depend on higher grain yield (Cassman et al., 2003) and more frequent harvests on the existing land (Ray and Foley, 2013).

Irrigated rice land contributes more than $75 \%$ of total rice production although it accounts for about $55 \%$ of total rice area. Unlike rainfed and upland rice systems, water is not a limiting factor for grain yield in irrigated rice system. Yield potential is defined as the yield obtained when an adapted cultivar is grown with the minimal possible stress that can be achieved with best management practices (Cassman, 1999). Climatic yield potential of irrigated rice is largely influenced by air temperature and solar radiation (Yoshida, 1981).

Plant maintenance respiration increases with increasing temperature (Amthor, 2000) and higher maintenance respiration reduces the amount of assimilates available for growth and yield formation (Monteith, 1981). In addition, high temperature may reduce biomass production and grain yield by accelerating the rate of development and thus shortening crop growth duration (Krishnan et al., 2011; Zhang et al., 2013). There is no 
doubt that high temperature associated with global warming will have a detrimental effect on rice production in the major rice growing areas (Welch et al., 2010).

On the other hand, it is generally believed that higher grain yield is associated with higher incident solar radiation and higher intercepted solar radiation by rice crop canopy (Katsura et al., 2008). This is because that crop canopy photosynthesis is largely driven by intercepted solar radiation during the growing season (Yoshida, 1981; Katsura et al., 2008). Yoshida (1981) stated that in both the tropics and the temperate regions, rice yield per hectare was primarily determined by the level of incident solar radiation. Within the tropics, when adequately managed, the dry season crop usually produces higher yields than the wet season crop because it receives more sunlight (Yoshida, 1981).

Large difference in grain yield has been reported between the single-season rice crop in the subtropical environment of Yunnan, China and the dry-season rice crop in the tropical environment of the International Rice Research Institute (IRRI) research farm (Ying et al., 1998). In that study, we could not determine the effects of temperature and solar radiation on the yield difference between the two environments because higher yield in the subtropical environment was mainly associated longer crop growth duration in the single-season rice in the subtropics compared with the double-season rice in the tropics. Within the subtropical environment, a study was conducted to compare the rice yield between Yunnan, China and Kyoto, Japan (Katsura et al., 2008). Yunnan had 33-39\% higher rice yield than Kyoto due to both higher average daily solar radiation and lower nighttime temperature during the mid-growth stage in Yunnan. Again, it was difficult to distinguish the individual effects of temperature and solar radiation on the variation of grain yield across Yunnan and Kyoto. Peng et al. (2004) reported that grain yield declines 
by $10 \%$ for each $1{ }^{\circ} \mathrm{C}$ increase in growing-season minimum temperature in rice crop grown under the irrigated conditions in the tropics. Sheehy et al. (2006) argued that solar radiation may be a confounding factor for the declined rice yields under warm nights because lower nighttime temperature was associated with high solar radiation. Overall, the impacts of temperature and solar radiation on rice yield remain imperfectly understood, despite decades of agronomic research (Welch et al., 2010; Tao et al., 2013).

In tropical and subtropical climates, rice can be grown two or even three times per year on the same field. In the subtropical environment of China, for example, double-season rice cropping is practiced with an early-season crop from April to July and a late-season crop from July to October. The typical double rice-growing seasons in the tropics are the dry season from January to April and the wet season from June to September. The wide adoption of double-season rice systems in both China and elsewhere in Asia increases total rice output per land area in production compared to single-season rice system and thus contributes substantially to global rice supply (Ray and Foley, 2013). However, the agronomic performance and its associated climatic factors of the double-season rice in the tropical and subtropical environments did not receive the same attention as the single-season rice.

The present study undertook a cross-location comparison approach between the tropical environment of IRRI research farm and the subtropical environment of Wuxue County, Hubei Province, China. At IRRI, field experiments were conducted in the dry and wet seasons from 2008 to 2010; and at Wuxue, field experiments were conducted in the early and late seasons from 2012 to 2014. At both sites, rice was grown with optimal management practices that minimized losses from all abiotic and biotic stresses so that 
yields obtained were assumed to be very close to yield potential. The objectives of this study were (1) to compare yield performance and RUE of double-season rice in tropical and subtropical environments, (2) to determine the effects of temperature and solar radiation on yield variation across the tropical and subtropical environments; and (3) to examine the effect of temperature on RUE. 


\section{Materials and methods}

\subsection{Experimental sites}

Field experiments were conducted in 2008-2010 in the tropical environment of IRRI,

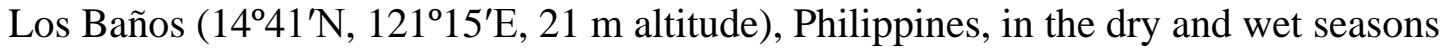
from January to October, and in 2012-2014 in the subtropical environment of Wuxue County $\left(29^{\circ} 51^{\prime} \mathrm{N} 115^{\circ} 33^{\prime} \mathrm{E}, 51 \mathrm{~m}\right.$ altitude), Hubei Province, China in the early and late seasons from April to October. The soil at IRRI site was an Aquandic Epiaquoll with $\mathrm{pH}$ 6.2, $20.0 \mathrm{~g} \mathrm{~kg}^{-1}$ organic $\mathrm{C}, 2.0 \mathrm{~g} \mathrm{~kg}^{-1}$ total $\mathrm{N}, 11.4 \mathrm{mg} \mathrm{kg}^{-1}$ Olsen $\mathrm{P}, 168.1 \mathrm{mg} \mathrm{kg}^{-1}$ exchangeable $\mathrm{K}$ and $34.5 \mathrm{cmol} \mathrm{kg}^{-1}$ cation exchange capacity; and $58.3 \%$ clay, $34.0 \%$ silt, $8.0 \%$ sand. The soil at Wuxue site has the following properties: $\mathrm{pH} 5.1,29.7 \mathrm{~g} \mathrm{~kg}^{-1}$ organic matter, $2.7 \mathrm{~g} \mathrm{~kg}^{-1}$ total $\mathrm{N}, 38.3 \mathrm{mg} \mathrm{kg}^{-1}$ Olsen $\mathrm{P}, 301.8 \mathrm{mg} \mathrm{kg}^{-1}$ exchangeable $\mathrm{K}$. The soil test was based on samples taken from the upper $20 \mathrm{~cm}$ of the soil before the application of basal fertilizers at both sites.

\subsection{Crop management}

At IRRI, rice varieties were IR82372H for the dry season and IR72 for the wet season. Fourteen-day-old seedlings were manually transplanted on January 23, 6, and 14 for the dry season, and on July 2, 10, and 8 for the wet season in 2008-2010, respectively. Four seedlings per hill were transplanted at a hill spacing of $20.0 \mathrm{~cm} \times 20.0 \mathrm{~cm}$. Total N rate was $200 \mathrm{~kg} \mathrm{ha}^{-1}$ for the dry season and $90-120 \mathrm{~kg} \mathrm{ha}^{-1}$ for the wet season. Fertilizers were manually broadcasted and incorporated 1 day before transplanting for the basal application: $60 \mathrm{~kg} \mathrm{~N} \mathrm{ha}^{-1}$ as urea, $30 \mathrm{~kg} \mathrm{Pha}^{-1}$ as single superphosphate, $40 \mathrm{~kg} \mathrm{~K} \mathrm{ha}^{-1}$ as potassium chloride, and $5 \mathrm{~kg} \mathrm{Zn} \mathrm{ha}^{-1}$ as zinc sulfate heptahydrate in the dry season for all three years. Basal fertilizer application in the wet season was the same as in the dry 
season except that the application rates were reduced by half. Nitrogen topdressings were applied at midtillering $\left(40 \mathrm{~kg} \mathrm{ha}^{-1}\right)$, panicle initiation $\left(60 \mathrm{~kg} \mathrm{ha}^{-1}\right)$, and booting $\left(40 \mathrm{~kg} \mathrm{ha}^{-1}\right)$ in the dry season for all three years. During the wet season, the rates of $\mathrm{N}$ topdressing were $30-30-30 \mathrm{~kg} \mathrm{~N}^{-1}$ in 2008, 20-30-20 in 2009, and 30-30-0 in 2010 at midtillering, panicle initiation, and booting, respectively.

At Wuxue, rice varieties were Liangyou 287 for the early season and Tianyouhuazhan for the late season. Thirty-eight- to 45-day-old seedlings were manually transplanted on April 27 in all three years for the early season, while 32- to 36-day-old seedlings were manually transplanted on July 20, 23, and 25 in 2012-2014 for the late season, respectively. Four seedlings per hill were transplanted at a hill spacing of $10.0 \mathrm{~cm}$ $\times 26.7 \mathrm{~cm}$. Total nutrient inputs were $244.0 \mathrm{~kg} \mathrm{~N} \mathrm{ha}^{-1}, 73.4 \mathrm{~kg} \mathrm{P} \mathrm{ha}^{-1}, 181.8 \mathrm{~kg} \mathrm{~K} \mathrm{ha}^{-1}$, and $6 \mathrm{~kg} \mathrm{Zn} \mathrm{ha}^{-1}$ for the early season, and $261.6 \mathrm{~kg} \mathrm{~N} \mathrm{ha}^{-1}, 50.9 \mathrm{~kg} \mathrm{P} \mathrm{ha}^{-1}, 205.0 \mathrm{~kg} \mathrm{~K} \mathrm{ha}^{-1}$, and $6 \mathrm{~kg} \mathrm{Zn} \mathrm{ha}{ }^{-1}$ for the late season in all three years. For basal N, 84 and $78.8 \mathrm{~kg} \mathrm{~N} \mathrm{ha}^{-1}$ as compound fertilizer, 119.7 and $53.8 \mathrm{~kg} \mathrm{~N} \mathrm{ha}^{-1}$ as ammonium acid carbonate were applied in the early and late season, respectively. For $\mathrm{N}$ topdressing, 24.2 and $80.7 \mathrm{~kg} \mathrm{~N}$ $\mathrm{ha}^{-1}$ at midtillering, 16.1 and $48.3 \mathrm{~kg} \mathrm{~N} \mathrm{ha}^{-1}$ at panicle initiation were applied as urea in the early and late season, respectively. All phosphorus was applied at basal with 36.7 and $34.4 \mathrm{~kg} \mathrm{P} \mathrm{ha}^{-1}$ as compound fertilizer, 36.7 and $16.5 \mathrm{~kg} \mathrm{P} \mathrm{ha}^{-1}$ as superphosphate in the early and late season, respectively. Basal $\mathrm{K}$ was applied at $69.7 \mathrm{~kg} \mathrm{~K} \mathrm{ha}^{-1}$ in the early season and $65.3 \mathrm{~kg} \mathrm{~K} \mathrm{ha}^{-1}$ in the late season as compound fertilizer. For $\mathrm{K}$ topdressing, 37.4 and $87.4 \mathrm{~kg} \mathrm{~K} \mathrm{ha}^{-1}$ at midtillering, 74.7 and $52.3 \mathrm{~kg} \mathrm{~K} \mathrm{ha}^{-1}$ at panicle initiation were applied as potassium chloride in the early and late season, respectively. Zinc as zinc sulfate heptahydrate was applied only at basal. 
In all experiments, rice varieties were chosen because of the local adaptation and high yield potential at their sites (Peng et al., 1999; Zhou et al., 2008; Zhang et al., 2012; Hu et al., 2015). Pre-germinated seeds were sown in seedling trays at IRRI and nursery bed at Wuxue to produce uniform seedlings. Nutrient management, seedling age, hill spacing, and number of seedlings per hill used were based on the common practices in that environment for achieving maximum yields. A water depth of 5 to $10 \mathrm{~cm}$ was maintained until 7 days before maturity when the fields were drained. Weeds, insects, and diseases were controlled as required to avoid yield loss.

\subsection{Measurements}

Sowing, transplanting, heading, and maturity dates were recorded for determining crop growth duration. At heading, 12 hills were chosen from each plot to measure leaf area index and aboveground total dry weight. Leaf area index was defined as the ratio of leaf area to ground area. Plants were separated into green leaves and stems. Green leaf area was measured with a leaf area meter (LI-3000, LI-COR Inc., Lincoln, NE, USA) and expressed as leaf area index. The dry weight of leaves and stems were determined after oven-drying at $70{ }^{\circ} \mathrm{C}$ to constant weight. At maturity, 12 hills were taken diagonally from a $5 \mathrm{~m}^{2}$ area in each plot where grain yield was determined to measure the plant height, aboveground total dry weight, harvest index, and yield components. Plant height was measured from the plant base to the tip of the highest leaf or panicle. Panicles of each hill were counted to determine the panicle number per $\mathrm{m}^{2}$. Plants were separated into straw and panicles. Panicles of all 12 hills were hand threshed and filled spikelets were separated from unfilled spikelets by submerging them in tap water. Three subsamples with each of $30 \mathrm{~g}$ filled spikelets and $10 \mathrm{~g}$ unfilled spikelets were taken to determine the 
number of spikelets. Dry weights of straw, rachis, and filled and unfilled spikelets were measured after oven drying at $70{ }^{\circ} \mathrm{C}$ to constant weight. Spikelets per panicle, grain filling percentage (100×filled spikelets/total spikelets), and harvest index (100×filled spikelet weight/aboveground total dry weight) were calculated. Grain yield was determined from a $5 \mathrm{~m}^{2}$ area in each plot and adjusted to the standard moisture content of $0.14 \mathrm{~g} \mathrm{H}_{2} \mathrm{O} \mathrm{g}^{-1}$ fresh weight. Grain moisture content was measured with a digital moisture tester (DMC-700, Seedburo, Chicago, IL, USA).

In both sites, climate data (daily solar radiation, minimum temperature, and maximum temperature) were collected from the weather station located within $2 \mathrm{~km}$ from the experimental sites. At IRRI, the Climate Computer (CLICOM) system, developed under the World Meteorological Organization, was used as the main database management tool. Solar radiation data were obtained from a Gunn-Bellani radiation integrator (Baird and Tatlock Limited, UK) included in the meteorological instruments at the station. Standard thermometers and psychrometers comparable with those used by the Philippine Atmospheric, Geophysical, and Astronomical Services Administration were acquired by the IRRI weather station. At Wuxue, a datalogger (CR800, Campbell Scientific Inc., Logan, Utah, USA) was used as the measurement and control module. A silicon pyranometer (LI-200, LI-COR Inc., Lincoln, NE, USA) and temperature/RH probe (HMP45C, Vaisala Inc., Helsinki, Finland) were used to measure total solar radiation and temperature, respectively.

Daily solar radiation from transplanting to maturity was used to determine seasonal accumulated solar radiation. Radiation use efficiency (RUE) was calculated as the ratio of biomass production to seasonal solar radiation from transplanting to maturity. Biomass 
production from transplanting to maturity was equal to the aboveground total dry weight at maturity minus seedling dry weight (excluding root dry weight) at transplanting. Seedling dry weight at transplanting was $1.21 \mathrm{~g} \mathrm{~m}^{-2}$ at IRRI and $28.40 \mathrm{~g} \mathrm{~m}^{-2}$ at Wuxue.

Canopy light interception rate (LI) was measured in the wet season of 2009 and dry season of 2010 at IRRI, and in the early and late seasons of 2014 at Wuxue. The measurements were taken between 1100 and $1300 \mathrm{~h}$ with an interval of 7-15 days during the growing season with a line ceptometer (AccuPAR LP-80, Decagon Devices Inc., Pullman, WA, USA). In each plot, light intensity inside the canopy was measured by placing the light bar in the middle of two rows and at approximately $5 \mathrm{~cm}$ above the water surface. Light intensity above the canopy was recorded immediately after the light measurement inside the canopy. Canopy light interception rate was calculated as the percentage of light intercepted by the canopy [100×(light intensity above canopy-light intensity below canopy)/light intensity above canopy]. Estimates of seasonal LI were made by linear interpolation of instantaneous measurements of LI with respect to days after transplanting according to Muurinen et al. (2006). Seasonal intercepted radiation during the entire growing season from transplanting to maturity was the product of seasonal LI and accumulated solar radiation during this growing period. Intercepted radiation use efficiency $\left(\mathrm{RUE}_{\mathrm{i}}\right)$ was calculated as the ratio of biomass production to seasonal intercepted solar radiation from transplanting to maturity. 


\section{Results}

Across sites and seasons, grain yield was the highest in the late season at Wuxue and the lowest in the wet season at IRRI, and there was insignificant difference in grain yield between the dry season at IRRI and the early season at Wuxue (Fig. 1a, b). Grain yield in the early season in 2013 at Wuxue was abnormal due to extremely high temperature during flowering (36.2-37.0 ${ }^{\circ} \mathrm{C}$ on June 17-19) as evidenced by a low grain filling percentage of $65.0 \%$ (Table 1). If the early season in 2013 at Wuxue was not considered, grain yield at Wuxue was 9-66\% higher than that at IRRI.

Among yield components, sink size (i.e. spikelets per $\mathrm{m}^{2}$ ) explained most of yield variation across seasons and sites (Table 1 and Fig. 2a). Sink size at Wuxue was 14-23\% and 56-68\% higher than that in the dry and wet seasons at IRRI, respectively. Within IRRI, sink size was $37 \%$ higher in the dry season than in the wet season. Panicles per $\mathrm{m}^{2}$ were also responsible for the yield difference between Wuxue and IRRI. There were inconsistent differences in spikelets per panicle, grain filling percentage, and 1000-grain weight between the two sites. Higher aboveground total dry weight at maturity and higher leaf area index at heading were found at Wuxue than at IRRI, whereas there were inconsistent differences in plant height at maturity and harvest index between the two sites (Table 2). Aboveground total dry weight at maturity at Wuxue was $6-18 \%$ and $38-53 \%$ higher than that in the dry and wet seasons at IRRI, respectively. Within IRRI, total dry weight was $30 \%$ higher in the dry season than in the wet season. Compared with harvest index, total dry weight was more important in explaining yield variation across seasons and sites (Table 2 and Fig. 2b).

There was small difference in crop development and total growth duration between 
the dry and wet seasons at IRRI (Table 3). Longer total growth duration was observed in the late season than in the early season at Wuxue, which was mainly due to the difference in the duration from heading to maturity. On average, the late season had 18 days longer duration from heading to maturity than the early season at Wuxue. Across sites, total growth duration was 10-23 days longer at Wuxue than at IRRI, which was mainly due to the difference in seedling age between the two sites. Seedling age at Wuxue was substantially longer than that at IRRI, whereas the duration from transplanting to heading at IRRI was longer than that at Wuxue. Crop growth duration in the main field (i.e. from transplanting to maturity) at Wuxue was similar to or shorter than that at IRRI.

Across sites, average daily minimum and maximum temperatures from transplanting to maturity were higher at IRRI than at Wuxue, and the difference between the two sites in minimum temperature was greater than in maximum temperature (Fig. 3a, b). From transplanting to heading, the early season at Wuxue had the lowest temperature among the four site-season combinations (Table 4). From heading to maturity, the late season at Wuxue had the lowest temperature among the four site-season combinations. Average daily minimum and maximum temperatures from transplanting to maturity at IRRI were 3.4 and $1.9^{\circ} \mathrm{C}$ higher than that at Wuxue, respectively.

Average daily solar radiation from transplanting to maturity in the dry season at IRRI was higher than that in the wet season at IRRI and in both early and late seasons at Wuxue (Fig. 3c). This difference was occurred mainly from heading to maturity (Table 4). There was inconsistent difference between the two sites in solar radiation from transplanting to heading. Seasonal solar radiation from transplanting to maturity was the highest in the dry season at IRRI and the lowest in the early season at Wuxue and there 
was no difference between the wet season at IRRI and late season at Wuxue (Fig. 3d). Overall, average daily solar radiation and seasonal solar radiation from transplanting to maturity at Wuxue was lower or similar to that at IRRI.

There was consistent and large difference in RUE between the two sites (Fig. 1c, d). The RUE at Wuxue was $48 \%$ higher than that at IRRI. Furthermore, there were inconsistent differences between Wuxue and IRRI in intercepted solar radiation rate and intercepted solar radiation by rice canopy from transplanting to maturity (Fig. 4a, b). Wuxue had on average 57\% higher biomass production per unit intercepted solar radiation (i.e. intercepted radiation use efficiency, $\mathrm{RUE}_{\mathrm{i}}$ ) than IRRI (Fig. 4c).

Significant relationship between grain yield and average daily minimum/maximum temperatures from transplanting to maturity was observed across sites, seasons, and years (Fig. 5a, b). Grain yield declined significantly when average daily minimum and maximum temperatures were greater than 22.0 and $29.5^{\circ} \mathrm{C}$, respectively. However, there was no relationship between grain yield and average daily solar radiation from transplanting to maturity (Fig. 5c). Across sites, seasons, and years, RUE was significantly correlated with average daily minimum and maximum temperatures (Fig. 5d, e), but was not correlated with average daily solar radiation from transplanting to maturity (Fig. 5f). 


\section{Discussion}

Previous study reported that the grain yield of single-season rice crop in the subtropical environment was significantly higher than that of double-season rice crop in the tropical environment (Ying et al., 1998). In present study, we compared the grain yield of double-season rice crop in the subtropics with that in the tropics and found that grain yield was $9-66 \%$ higher in the subtropics than in the tropics. This difference was mainly due to the low grain yield in the wet season at IRRI. Within IRRI, grain yield was $45 \%$ higher in the dry season than in the wet season. Grain yield in the dry season at IRRI was 8.74-9.19 $\mathrm{t} \mathrm{ha}^{-1}$, which is close to the yield potential of tropical irrigated lowland rice (Peng et al., 1999). Average grain yield of $6.21 \mathrm{t} \mathrm{ha}^{-1}$ in the wet season at IRRI was similar to the grain yield reported by others under tropical wet-season conditions when grown with optimal crop management practices (Laza et al., 2003; Yang et al., 2008).

Both of sink size and biomass production were responsible for the yield difference between the tropical and subtropical environments, which was in consistent with the finding in a previous study (Ying et al., 1998). It is also reported that sink size and biomass were mainly responsible for the yield difference between the dry and wet seasons in the tropics (Yang et al., 2008). Harvest index, spikelets per panicle, grain filling percentage, and 1000-grain weight did not explain the high grain yield of double-season rice under subtropical conditions.

Maximum grain yield of 13.0-16.5 $\mathrm{tha}^{-1}$ was reported in the subtropical environment of Yunnan, China (Ying et al., 1998; Katsura et al., 2008) and in the temperate environment of Yanco, Australia (Williams, 1992). It is generally believed that these high yields are mainly due to longer growth duration because total growth duration 
of these subtropical and temperate rice crops is on average 40 days longer than that in the tropics (Ying et al., 1998). In this study, when we compared the growth duration of the double-season rice crops between tropical and subtropical environments, the difference was only 10-23 days (Table 3). Such difference was entirely due to longer duration of seedbed at Wuxue than at IRRI because the growth duration in the main field from transplanting to maturity at Wuxue was either equal or shorter than that at IRRI.

Therefore, yield advantage of the double-season rice crop in the subtropical environment compared with the tropical environment was not attributed to long growth duration. This statement is also supported by the fact that crop growth rate at Wuxue was 14-66\% higher than that at IRRI (Table 2).

Both air temperature and solar radiation have a large influence on the yield potential of irrigated rice (Yoshida, 1981). However, previous studies suggested that rice yield was primarily determined by the level of incident solar radiation (Evans and De Datta, 1979; Yoshida, 1981). It is generally believed that rice yield difference between the dry and wet seasons in the tropical environment is due to the difference in solar radiation between the two seasons, especially during ripening phase (Yoshida, 1981; Yang et al., 2008). There is a tendency to overlook the fact that a large difference in both daily minimum and maximum temperatures exists between the dry and wet seasons, which could be more responsible for the yield difference between the two seasons compared with solar radiation. In present study, rice yield was significantly higher at Wuxue than at IRRI, although average daily solar radiation and seasonal solar radiation were not higher at Wuxue than at IRRI. Average daily minimum and maximum temperatures from transplanting to maturity at Wuxue were significantly lower than that at IRRI. 
Furthermore, grain yield was significantly correlated with average daily minimum and maximum temperatures, but not with average daily solar radiation from transplanting to maturity (Fig. 5a-c). Therefore, there was a large effect of temperature on rice grain yield when solar radiation and crop growth duration were not confounding factors for explaining yield difference across the two locations in the tropical and subtropical environments.

Crop biomass production is function of the seasonal accumulation of solar radiation and RUE (Monteith, 1977). In the present study, Wuxue had consistently higher RUE and RUE $_{\mathrm{i}}$ than IRRI. Because Wuxue did not have higher solar radiation than IRRI, the yield difference in double-season rice crop between the tropical and subtropical environments was mainly associated with the difference in RUE. Radiation use efficiency can be affected by variety, nitrogen management, and climatic conditions (Sinclair and Horie, 1989; Katsura et al., 2007; Zhu et al., 2008). Although different varieties were used across seasons and sites in the present study, they had local adaptation and high yield potential for their particular seasons and sites (Peng et al., 1999; Zhou et al., 2008; Zhang et al., 2012; Hu et al., 2015). Difference in RUE is very small among the high-yielding rice varieties (Katsura et al., 2007, 2008; Zhang et al., 2009). This is because there has been little or no genetic improvement in RUE despite that large gains in yield potential were achieved through rice breeding (Long et al., 2015). In both sites, optimal crop management was practiced for achieving highest possible grain yield in both seasons, therefore, it was unlikely that fertilizer management and crop establishment limited RUE at IRRI and Wuxue. Among climatic parameters, solar radiation and temperature could affect RUE significantly at the leaf level (Zhu et al., 2008). At high solar radiation, RUE 
can be reduced because the increase in photosynthesis with further increase in light diminishes and excess energy will engage photoprotective mechanisms (Ort, 2001). Temperature affects both the solubility of $\mathrm{CO}_{2}$ and $\mathrm{O}_{2}$ as well as the specificity of Rubisco to $\mathrm{CO}_{2}$ relative to $\mathrm{O}_{2}$, which together cause the decline in RUE with increase in temperature at the leaf level (Zhu et al., 2008). High temperature also reduces RUE by enhancing crop respiration (Monteith, 1981; Amthor, 2000).

Limited information is available on the effects of temperature on RUE at the field level. In the present study, average daily solar radiation from transplanting to maturity in the dry season at IRRI was higher than that at Wuxue, but there was no significant difference between IRRI wet season and Wuxue (Fig. 3c). Furthermore, there was no relationship between RUE and average daily solar radiation from transplanting to maturity (Fig. 5f). Therefore, solar radiation was unlikely the cause for the large difference in RUE between the two sites. On the other hand, average daily minimum and maximum temperature from transplanting to maturity at IRRI was 3.4 and $1.9^{\circ} \mathrm{C}$ higher than that at Wuxue, respectively (Fig. 3a, b). This suggests that higher RUE in the subtropical environment was associated with the lower temperature compared with the tropical environment and high temperature in the tropics reduced RUE significantly.

One would argue that differences in varieties, other climatic factors such as humidity, and crop management practices could affect yield performance of rice crop in the tropical and subtropical environments. By definition, yield potential is the yield obtained with adapted varieties grown under the best management practices (Cassman, 1999) and climatic yield potential of irrigated rice is largely determined by air temperature and solar radiation (Yoshida, 1981). The grain yield from our study 
approached the yield potential of the double season rice grown under both seasons and both sites because we used adapted varieties and optimum crop management practices (Yang et al., 2008; Zhou et al., 2008; Hu et al., 2015). Under such circumstance, although differences in varieties, other climatic factors such as humidity, and crop management practices could potentially cause yield variation across seasons and sites, their impact on yield was relatively small compared with temperature and solar radiation. 


\section{Conclusion}

Double-season rice crop in the subtropical environment demonstrated higher grain yield than that in the tropical environment. Sink size and biomass production were mainly responsible for the yield difference. Harvest index and crop growth duration did not explain the high grain yield of double-season rice under subtropical environment. Higher biomass production and grain yield in the subtropical environment was due to higher RUE compared with the tropical environment. Higher temperature was mainly responsible for lower RUE in the tropical environment. Temperature explained the yield difference of the double-season rice between the tropical and subtropical environments without the confounding effects of solar radiation and crop growth duration. These results suggest that high temperature reduced rice grain yield by decreasing RUE. 


\section{Acknowledgements}

We thank Canjin Zhou, Guanglong Zhu, Guohui Li, Shen Yuan, Anicio Macahia, Onofre Mendoza, Maximo Pelagio, Eduardo Tandang, Siena Calibo and Rowena Noblejas for help with field experiments. This work was supported by the Program of Introducing Talents of Discipline to Universities in China (the 111 Project no. B14032), the Special Fund for Agro-scientific Research in the Public Interest of China from the Ministry of Agriculture (No. 201203096), the National High Technology Research and Development Program of China (the 863 Project no. 2014AA10A605), and the Major International Joint Research Project of China National Science Foundation (31361140368). 


\section{References}

Amthor, J.S, 2000. The McCree-de Wit-Penning de Vires-Thornley respiration paradigms: 30 years later. Ann. Bot. 86, 1-20.

Cassman, K.G., 1999. Ecological intensification of cereal production systems: Yield potential, soil quality, and precision agriculture. Proc. Natl. Acad. Sci. U.S.A. 96, $5952-5959$.

Cassman, K.G., Dobermann, A., Walters, D.T., Yang, H., 2003. Meeting cereal demand while protecting natural resources and improving environmental quality. Annu. Rev. Environ. Resour. 28, 315-358.

Evans, L.T., De Datta, S.K., 1979. The relationship between irradiance and grain yield of irrigated rice in the tropics, as influenced by cultivar, nitrogen fertilizer application and month of planting. Field Crops Res. 2, 1-17.

FAO, 2015. FAOSTAT, FAO Statistical databases. Food and Agriculture Organization (FAO) of the United Nations, Rome, Italy. http://faostat3.fao.org/home/E.

Hu, Z., Liu, Y., Huang, L., Peng, S., Nie, L., Cui, K., Huang, J., Wang, F., 2015. Premature heading and yield losses caused by prolonged seedling age in double cropping rice. Field Crops Res. 183, 147-155.

Katsura, K., Maeda, S., Horie, T., Shiraiwa, T., 2007. Analysis of yield attributes and crop physiological traits of Liangyoupeijiu, a hybrid rice recently bred in China. Field Crops Res. 103, 170-177.

Katsura, K., Maeda, S., Lubis, I., Horie, T., Cao, W., Shiraiwa, T., 2008. The high yield of irrigated rice in Yunnan China: a cross-location analysis. Field Crops Res. 101, $1-11$. 
Krishnan, R., Ramakrishnan, B., Reddy, K.R., Reddy, V.R., 2011. High-temperature effects on rice growth, yield, and grain quality. Adv. Agron. 111, 87-206.

Laza, R.C., Peng, S., Akita, S., Saka, H., 2003. Contribution of biomass partitioning and translocation to grain yield under sub-optimum growing conditions in irrigated rice. Plant Prod. Sci. 6, 28-35.

Long, S.P., 2014. We need winners in the race to increase photosynthesis in rice, whether from conventional breeding, biotechnology or both. Plant, Cell \& Environ. 37, $19-21$.

Long, S.P., Marshall-Colon, A., Zhu, X., 2015. Meeting the global food demand of the future by engineering crop photosynthesis and yield potential. Cell 161, 56-66.

Maclean, J.L., Dawe, D.C., Hardy, B., Hettel, G.P., 2002. Rice Almanac, Third Edition, International Rice Research Institute (IRRI), Los Baños, Philippines. 1-253.

Monteith, J.L., 1977. Climate and the efficiency of crop production in Britain. Philos. Trans. R. Soc. B Biol. Sci. 281, 277-294.

Monteith, J.L., 1981. Climatic variations and the growth of crops. Q. J. Roy. Meteor Soc. 107, 749-774.

Muurinen, S., Peltonen-Sainio, P., 2006. Radiation-use efficiency of modern and old spring cereal cultivars and its response to nitrogen in northern growing conditions. Field Crops Res. 96, 363-373.

Ort, D.R., 2001. When there is too much light. Plant Physiol. 125, 29-32.

Peng, S., Cassman, K.G., Virmani, S.S., Sheehy, J.E., Khush, G.S., 1999. Yield potential trends of tropical rice since the release of IR8 and the challenge of increasing rice yield potential. Crop Sci. 39, 1552-1559. 
Peng, S., Huang, J., Sheehy, J.E., Laza, R.C., Visperas, R.M., Zhong, X., Centeno, G.S., Khush, G.S., Cassman, K.G., 2004. Rice yields decline with higher night temperature from global warming. Proc. Natl. Acad. Sci. U.S.A. 101, 9971-9975.

Ray, D.K., Foley, J.A., 2013. Increasing global crop harvest frequency: recent trends and future directions. Environ. Res. Lett. 8(4), 044041.

Sheehy, J.E., Mitchell, P.L., Ferrer, A.B., 2006. Decline in rice grain yields with temperature: Models and correlations can give different estimates. Field Crops Res. 98, 151-156.

Sinclair, T.R., Horie, T., 1989. Leaf nitrogen, photosynthesis, and crop radiation use efficiency: a review. Crop Sci. 29, 90-98.

Tao, F., Zhang, Z., Shi, W., Liu, Y., Xiao, D., Zhang, S., Zhu, Z., Wang, M., Liu, F., 2013. Single rice growth period was prolonged by cultivars shifts, but yield was damaged by climate change during 1981-2009 in China, and late rice was just opposite. Global Change Biol. 19, 3200-3209.

Welch, J.R., Vincent, J.R., Auffhammer, M., Moya, P.F., Dobermann, A., Dawe, D., 2010. Rice yields in tropical/subtropical Asia exhibit large but opposing sensitivities to minimum and maximum temperatures. Proc. Natl. Acad. Sci. U.S.A. 107, $14562-14567$.

Williams, R.L., 1992. Yanco Agricultural Annual Report (eds. Beecher HG, Dunn BW), pp. 81-85. Yanco Agricultural Institute, NSW, Australia.

Yang, W., Peng, S., Laza, R.C., Visperas, R.M., Dionisio-Sese, M.L., 2008. Yield gap analysis between dry and wet season rice crop grown under high-yielding management conditions. Agron. J. 100, 1390-1395. 
Ying, J., Peng, S., He, Q., Yang, H., Yang, C., Visperas, R.M., Cassman, K.G., 1998. Comparison of high-yield rice in tropical and subtropical environments: I.

Determinants of grain and dry matter yields. Field Crops Res. 57, 71-84.

Yoshida, S., 1981. Fundamentals of Rice Crop Science. International Rice Research Institute, Los Baños, Philippines.

Zhang, T., Huang, Y., Yang, X., 2013. Climate warming over the past three decades has shortened rice growth duration in China and cultivar shifts have further accelerated the process for late rice. Global Change Biol. 19, 563-570.

Zhang, Y., Tang, Q., Peng, S., Xing, D., Qin, J., Laza, R.C., Punzalan, B.R., 2012. Water use efficiency and physiological response of rice cultivars under alternate wetting and drying conditions. The Sci. World J. doi:10.1100/2012/287907.

Zhang, Y., Tang, Q., Zou, Y., Li, D., Qin, J., Yang, S., Chen, L., Xia, B., Peng, S., 2009. Yield potential and radiation use efficiency of "super" hybrid rice grown under subtropical conditions. Field Crops Res. 114, 91-98.

Zhou, Y., Ju, C., Xu, G., Xie, P., Gao, M., 2008. Liangyou-287, a new two-line early cropping super hybrid rice combination with fine grain quality. Hybrid Rice 23, 71-72 (in Chinese).

Zhu, X., Long, S.P., Ort, D.R., 2008. What is the maximum efficiency with which photosynthesis can convert solar energy into biomass? Curr. Opin. Biotech. 19, $153-159$. 
Table 1. Yield components in the dry and wet seasons at IRRI in 2008-2010, and in the early and late seasons at Wuxue in 2012-2014.

\begin{tabular}{|c|c|c|c|c|c|c|c|}
\hline Site & Season & Year & $\begin{array}{l}\text { Panicles } \\
\mathrm{m}^{-2}\end{array}$ & $\begin{array}{l}\text { Spikelets } \\
\text { panicle }^{-1}\end{array}$ & $\begin{array}{l}\text { Spikelets } \\
\mathrm{m}^{-2}\left(\times 10^{3}\right)\end{array}$ & $\begin{array}{l}\text { Grain } \\
\text { filling }(\%)\end{array}$ & $\begin{array}{l}\text { 1000-grain } \\
\text { weight }(\mathrm{g})\end{array}$ \\
\hline \multirow[t]{8}{*}{ IRRI } & \multirow[t]{4}{*}{ Dry } & 2008 & $388.5 \pm 13.2^{\mathrm{a}}$ & $105.2 \pm 8.6$ & $40.9 \pm 4.0$ & $84.7 \pm 1.7$ & $25.0 \pm 0.1$ \\
\hline & & 2009 & $363.0 \pm 22.5$ & $117.8 \pm 5.8$ & $42.8 \pm 3.8$ & $77.8 \pm 4.0$ & $24.3 \pm 0.3$ \\
\hline & & 2010 & $429.2 \pm 12.8$ & $103.9 \pm 5.6$ & $44.6 \pm 1.8$ & $85.3 \pm 7.8$ & $23.7 \pm 0.1$ \\
\hline & & Mean & 393.6 & 109.0 & 42.8 & 82.6 & 24.3 \\
\hline & \multirow[t]{4}{*}{ Wet } & 2008 & $387.5 \pm 21.2$ & $84.0 \pm 3.2$ & $32.5 \pm 0.8$ & $82.5 \pm 2.5$ & $22.4 \pm 0.1$ \\
\hline & & 2009 & $363.0 \pm 18.4$ & $80.7 \pm 3.5$ & $29.2 \pm 0.5$ & $78.2 \pm 2.5$ & $22.2 \pm 0.2$ \\
\hline & & 2010 & $405.2 \pm 22.1$ & $79.6 \pm 8.9$ & $32.1 \pm 2.5$ & $76.4 \pm 7.5$ & $22.6 \pm 0.2$ \\
\hline & & Mean & 385.2 & 81.4 & 31.3 & 79.0 & 22.4 \\
\hline \multirow[t]{8}{*}{ Wuxue } & \multirow[t]{4}{*}{ Early } & 2012 & $480.5 \pm 19.3$ & $103.6 \pm 10.0$ & $49.7 \pm 4.0$ & $85.2 \pm 1.2$ & $21.1 \pm 0.1$ \\
\hline & & 2013 & $498.8 \pm 14.1$ & $101.9 \pm 3.9$ & $50.8 \pm 2.2$ & $65.0 \pm 1.6$ & $22.6 \pm 0.1$ \\
\hline & & 2014 & $402.3 \pm 14.1$ & $114.2 \pm 1.0$ & $46.0 \pm 1.3$ & $82.2 \pm 0.8$ & $24.1 \pm 0.2$ \\
\hline & & Mean & 460.5 & 106.6 & 48.8 & 77.5 & 22.6 \\
\hline & \multirow[t]{4}{*}{ Late } & 2012 & $473.7 \pm 29.6$ & $105.6 \pm 4.5$ & $50.0 \pm 3.6$ & $76.3 \pm 1.7$ & $22.9 \pm 0.2$ \\
\hline & & 2013 & $395.6 \pm 6.7$ & $142.4 \pm 5.7$ & $56.3 \pm 2.4$ & $78.3 \pm 1.9$ & $22.4 \pm 0.2$ \\
\hline & & 2014 & $380.5 \pm 13.6$ & $134.3 \pm 2.3$ & $51.1 \pm 1.1$ & $80.7 \pm 1.1$ & $23.2 \pm 0.1$ \\
\hline & & Mean & 416.6 & 127.4 & 52.5 & 78.4 & 22.8 \\
\hline
\end{tabular}

${ }^{\mathrm{a}}$ Means \pm s.d. ( $\mathrm{n}=4$, standard deviation of four replications). 
Table 2. Crop growth and harvest index in the dry and wet seasons at IRRI in 2008-2010, and in the early and late seasons at Wuxue in 2012-2014.

\begin{tabular}{|c|c|c|c|c|c|c|c|}
\hline Site & Season & Year & $\begin{array}{l}\text { Leaf } \\
\text { area } \\
\text { index }^{\mathrm{a}}\end{array}$ & $\begin{array}{l}\text { Plant } \\
\text { height } \\
(\mathrm{cm})\end{array}$ & $\begin{array}{l}\text { Total dry } \\
\text { weight } \\
\left(\mathrm{g} \mathrm{m}^{-2}\right)\end{array}$ & $\begin{array}{l}\text { Crop } \\
\text { growth rate } \\
\left(\mathrm{g} \mathrm{m}^{-2} \mathrm{~d}^{-1}\right)\end{array}$ & $\begin{array}{l}\text { Harvest } \\
\text { index } \\
(\%)\end{array}$ \\
\hline \multirow[t]{8}{*}{ IRRI } & \multirow[t]{4}{*}{ Dry } & 2008 & $5.15 \pm 0.64^{\mathrm{b}}$ & $115.6 \pm 1.6$ & $1634 \pm 139$ & $16.3 \pm 1.4$ & $52.9 \pm 2.0$ \\
\hline & & 2009 & $7.29 \pm 0.58$ & $123.8 \pm 1.5$ & $1568 \pm 85$ & $15.5 \pm 0.8$ & $51.4 \pm 1.0$ \\
\hline & & 2010 & $5.83 \pm 0.33$ & $117.9 \pm 2.3$ & $1741 \pm 175$ & $17.4 \pm 1.7$ & $51.7 \pm 2.3$ \\
\hline & & Mean & 6.09 & 119.1 & 1648 & 16.4 & 52.0 \\
\hline & \multirow[t]{4}{*}{ Wet } & 2008 & $3.96 \pm 0.41$ & $101.9 \pm 2.7$ & $1338 \pm 36$ & $13.5 \pm 0.4$ & $44.7 \pm 1.3$ \\
\hline & & 2009 & $3.73 \pm 0.29$ & $97.1 \pm 2.9$ & $1192 \pm 27$ & $11.7 \pm 0.3$ & $42.6 \pm 1.2$ \\
\hline & & 2010 & $4.91 \pm 0.64$ & $108.2 \pm 2.0$ & $1269 \pm 115$ & $12.4 \pm 1.1$ & $43.6 \pm 1.2$ \\
\hline & & Mean & 4.20 & 102.4 & 1266 & 12.5 & 43.7 \\
\hline \multirow[t]{8}{*}{ Wuxue } & \multirow[t]{4}{*}{ Early } & 2012 & $-{ }^{c}$ & $89.9 \pm 1.8$ & $1601 \pm 132$ & $19.5 \pm 1.6$ & $54.8 \pm 1.3$ \\
\hline & & 2013 & $7.91 \pm 0.13$ & $101.3 \pm 2.0$ & $1883 \pm 95$ & $23.0 \pm 1.2$ & $39.2 \pm 0.8$ \\
\hline & & 2014 & $6.68 \pm 0.17$ & $90.1 \pm 2.8$ & $1674 \pm 42$ & $19.7 \pm 0.5$ & $53.5 \pm 1.0$ \\
\hline & & Mean & 7.30 & 93.7 & 1719 & 20.7 & 49.2 \\
\hline & \multirow[t]{4}{*}{ Late } & 2012 & $7.20 \pm 0.43$ & $115.1 \pm 2.8$ & $1971 \pm 115$ & $18.3 \pm 1.1$ & $43.6 \pm 0.6$ \\
\hline & & 2013 & $7.13 \pm 0.35$ & $106.3 \pm 1.4$ & $1948 \pm 85$ & $18.6 \pm 0.8$ & $50.1 \pm 1.5$ \\
\hline & & 2014 & $8.17 \pm 0.66$ & $103.6 \pm 0.7$ & $1832 \pm 22$ & $19.3 \pm 0.2$ & $51.4 \pm 1.3$ \\
\hline & & Mean & 7.50 & 108.3 & 1917 & 18.7 & 48.3 \\
\hline
\end{tabular}

${ }^{\mathrm{a}}$ Leaf area index at heading, plant height and aboveground total dry weight at maturity, and crop growth rate from transplanting to maturity.

${ }^{b}$ Means \pm s.d. ( $n=4$, standard deviation of four replications).

${ }^{\mathrm{c}}$ Not measured. 
Table 3. Growth duration (days) in the dry and wet seasons at IRRI in 2008-2010, and in the early and late seasons at Wuxue in 2012-2014.

\begin{tabular}{|c|c|c|c|c|c|c|c|}
\hline Site & Season & Year & Seedbed $^{\mathrm{a}}$ & $\begin{array}{l}\text { TR to } \\
\text { heading }\end{array}$ & $\begin{array}{l}\text { Ripening } \\
\text { phase }\end{array}$ & $\begin{array}{l}\text { Main } \\
\text { field }\end{array}$ & Total \\
\hline \multirow[t]{8}{*}{ IRRI } & \multirow[t]{4}{*}{ Dry } & 2008 & 14 & 63 & 37 & 100 & 114 \\
\hline & & 2009 & 14 & 64 & 37 & 101 & 115 \\
\hline & & 2010 & 14 & 61 & 39 & 100 & 114 \\
\hline & & Mean & 14 & 63 & 38 & 100 & 114 \\
\hline & \multirow[t]{4}{*}{ Wet } & 2008 & 14 & 65 & 34 & 99 & 113 \\
\hline & & 2009 & 14 & 67 & 35 & 102 & 116 \\
\hline & & 2010 & 14 & 64 & 38 & 102 & 116 \\
\hline & & Mean & 14 & 65 & 36 & 101 & 115 \\
\hline \multirow[t]{8}{*}{ Wuxue } & \multirow[t]{4}{*}{ Early } & 2012 & 38 & 55 & 27 & 82 & 120 \\
\hline & & 2013 & 45 & 55 & 27 & 82 & 127 \\
\hline & & 2014 & 43 & 53 & 32 & 85 & 128 \\
\hline & & Mean & 42 & 54 & 29 & 83 & 125 \\
\hline & \multirow[t]{4}{*}{ Late } & 2012 & 32 & 60 & 48 & 108 & 140 \\
\hline & & 2013 & 36 & 57 & 48 & 105 & 141 \\
\hline & & 2014 & 36 & 49 & 46 & 95 & 131 \\
\hline & & Mean & 35 & 55 & 47 & 103 & 137 \\
\hline
\end{tabular}


Table 4. Climate conditions in the dry and wet seasons at IRRI in 2008-2010, and in the early and late seasons at Wuxue in 2012-2014.

\begin{tabular}{|c|c|c|c|c|c|c|c|c|}
\hline \multirow[t]{2}{*}{ Site } & \multirow[t]{2}{*}{ Season } & \multirow[t]{2}{*}{ Year } & \multicolumn{3}{|c|}{ Transplanting-Heading $^{\mathrm{a}}$} & \multicolumn{3}{|c|}{ Heading-Maturity } \\
\hline & & & $\overline{\operatorname{Min}} \mathrm{T}^{\mathrm{b}}$ & $\operatorname{Max} \mathrm{T}$ & Radiation & Min $\mathrm{T}$ & $\operatorname{Max} \mathrm{T}$ & Radiation \\
\hline \multirow[t]{8}{*}{ IRRI } & \multirow[t]{4}{*}{ Dry } & 2008 & 23.1 & 28.8 & 14.7 & 24.5 & 32.3 & 18.0 \\
\hline & & 2009 & 23.2 & 28.8 & 13.7 & 24.0 & 31.6 & 19.2 \\
\hline & & 2010 & 22.5 & 29.9 & 17.7 & 23.9 & 31.6 & 20.0 \\
\hline & & Mean & 22.9 & 29.2 & 15.3 & 24.1 & 31.8 & 19.1 \\
\hline & \multirow[t]{4}{*}{ Wet } & 2008 & 24.3 & 31.4 & 15.4 & 24.3 & 31.4 & 15.2 \\
\hline & & 2009 & 25.0 & 31.3 & 13.4 & 24.8 & 31.3 & 14.2 \\
\hline & & 2010 & 24.5 & 31.6 & 14.9 & 24.7 & 31.4 & 14.9 \\
\hline & & Mean & 24.6 & 31.4 & 14.6 & 24.6 & 31.4 & 14.8 \\
\hline \multirow[t]{8}{*}{ Wuxue } & \multirow[t]{4}{*}{ Early } & 2012 & 20.4 & 27.7 & 14.9 & 25.3 & 32.3 & 16.5 \\
\hline & & 2013 & 20.2 & 28.0 & 15.0 & 25.3 & 32.0 & 15.0 \\
\hline & & 2014 & 19.3 & 27.9 & 14.8 & 23.5 & 29.5 & 11.8 \\
\hline & & Mean & 20.0 & 27.9 & 14.9 & 24.7 & 31.2 & 14.4 \\
\hline & \multirow[t]{4}{*}{ Late } & 2012 & 23.5 & 31.1 & 17.4 & 13.9 & 23.9 & 11.8 \\
\hline & & 2013 & 24.5 & 32.9 & 17.8 & 13.9 & 25.4 & 11.4 \\
\hline & & 2014 & 23.2 & 31.0 & 13.4 & 16.9 & 26.8 & 12.2 \\
\hline & & Mean & 23.7 & 31.6 & 16.2 & 14.9 & 25.4 & 11.8 \\
\hline
\end{tabular}

${ }^{a}$ Average from transplanting to heading, and from heading to maturity, respectively.

${ }^{\mathrm{b}}$ Average daily minimum temperature (Min $\mathrm{T},{ }^{\circ} \mathrm{C}$ ), average daily maximum temperature (Max $\left.\mathrm{T},{ }^{\circ} \mathrm{C}\right)$, and average daily solar radiation $\left(\mathrm{MJ} \mathrm{m}^{-2} \mathrm{day}^{-1}\right)$ for each growing period. 


\section{Figure legends}

Fig. 1. Grain yield and radiation use efficiency (RUE) in the dry and wet seasons at IRRI in 2008-2010 (a, c), and in the early and late seasons at Wuxue in 2012-2014 (b, d). Radiation use efficiency was calculated as the ratio of aboveground total dry weight production to seasonal solar radiation from transplanting to maturity. Error bars represent \pm 1 s.d. ( $\mathrm{n}=4$, standard deviation of four replications).

Fig. 2. The relationship of grain yield with spikelets per $\mathrm{m}^{2}$ and aboveground total dry weight at maturity. Open and closed symbols were for IRRI and Wuxue, respectively. Data $(n=12)$ were pooled from experiments conducted in the dry and wet seasons at IRRI in 2008-2010, and in the early and late seasons at Wuxue in 2012-2014. Datum point in circle was an outlier from the early season at Wuxue in 2013 when extremely high temperature occurred during flowering and reduced grain filling percentage and grain yield significantly.

Fig. 3. Average daily minimum temperature (a), average daily maximum temperature (b), average daily solar radiation (c), seasonal solar radiation (d) in the dry and wet seasons at IRRI, and in the early and late seasons at Wuxue. All parameters were calculated from transplanting to maturity. Error bars represent \pm 1 s.d. $(n=3$, standard deviation of three years).

Fig. 4. Intercepted solar radiation rate (a), intercepted solar radiation (b) and intercepted 
radiation use efficiency $\left(\mathrm{RUE}_{\mathrm{i}}, \mathrm{c}\right)$ in the dry season (DS) of 2010 and wet season (WS) of 2009 at IRRI (IR), and in the early season (ES) and late season (LS) of 2014 at Wuxue (WX). $\mathrm{RUE}_{\mathrm{i}}$ was calculated as the ratio of aboveground total dry weight production to seasonal intercepted solar radiation from transplanting to maturity. Error bars represent \pm 1 s.d. ( $\mathrm{n}=4$, standard deviation of four replications).

Fig. 5. The relationship of grain yield (a-c) and radiation use efficiency (RUE, d-f) with climate conditions. Open and closed symbols were for IRRI and Wuxue, respectively. Climatic parameters were the averages from transplanting to maturity. Data $(n=12)$ were pooled from experiments conducted in the dry and wet seasons at IRRI in 2008-2010, and in the early and late seasons at Wuxue in 2012-2014. Datum point in circle was an outlier from the early season at Wuxue in 2013 when extremely high temperature occurred during flowering and reduced grain filling percentage and grain yield significantly. 
Figure 1

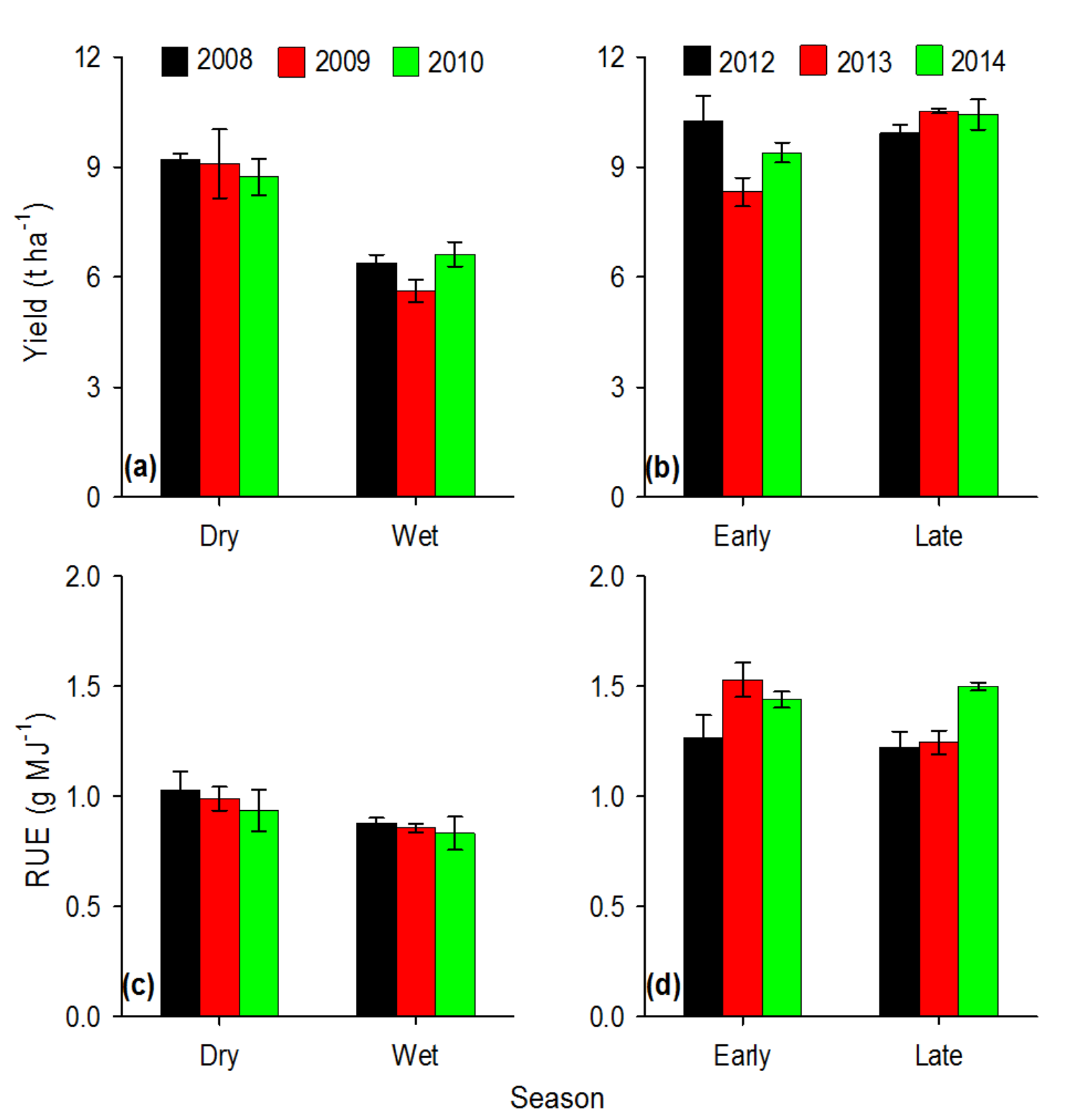

Fig. 1. Grain yield and radiation use efficiency (RUE) in the dry and wet seasons at IRRI in 2008-2010 (a, c), and in the early and late seasons at Wuxue in 2012-2014 (b, d). Radiation use efficiency was calculated as the ratio of aboveground total dry weight production to seasonal solar radiation from transplanting to maturity. Error bars represent \pm 1 s.d. ( $\mathrm{n}=4$, standard deviation of four replications). 
Figure 2

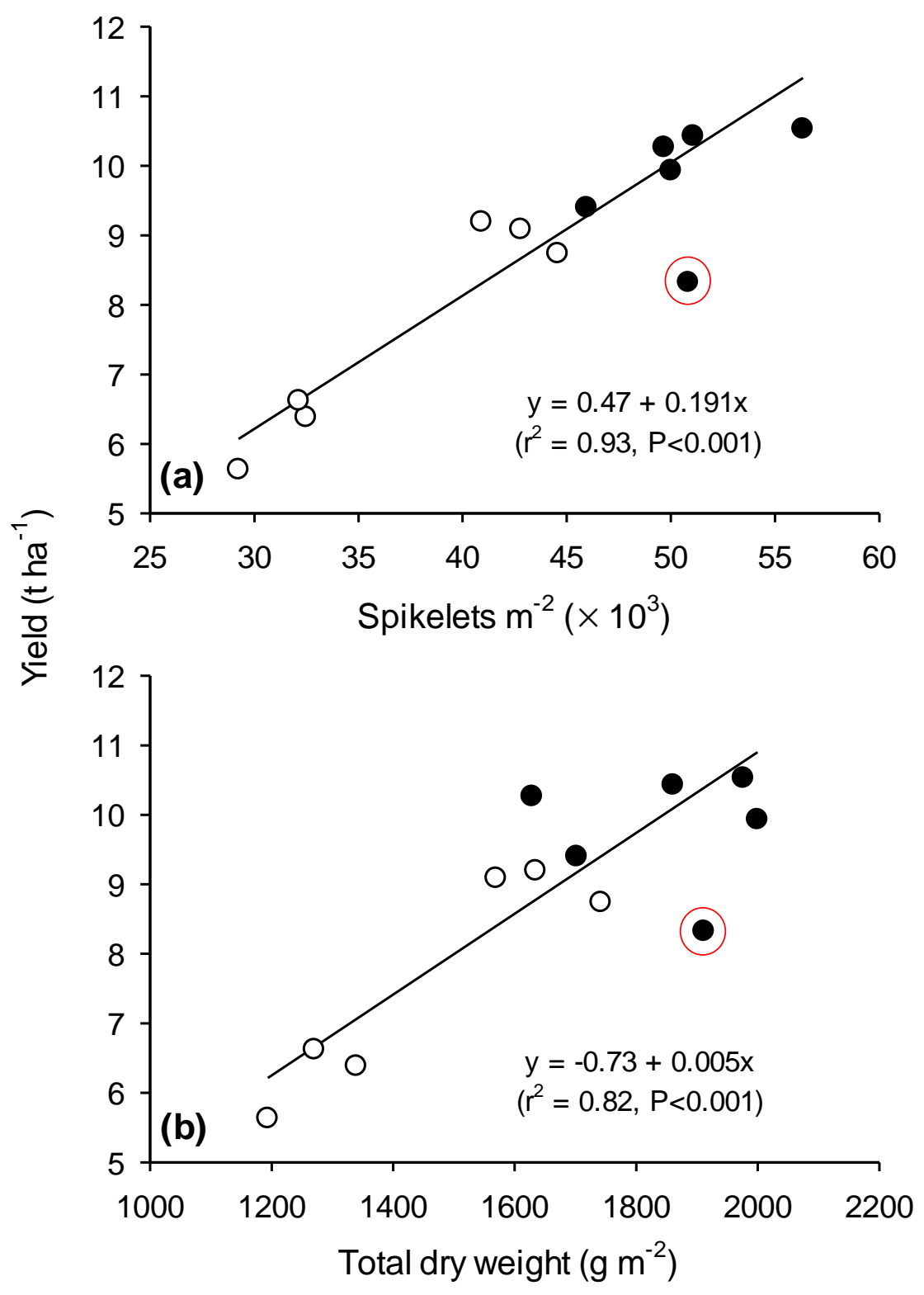

Fig. 2. The relationship of grain yield with spikelets per $\mathrm{m}^{2}$ and aboveground total dry weight at maturity. Open and closed symbols were for IRRI and Wuxue, respectively. Data $(n=12)$ were pooled from experiments conducted in the dry and wet seasons at IRRI in 2008-2010, and in the early and late seasons at Wuxue in 2012-2014. Datum point in circle was an outlier from the early season at Wuxue in 2013 when extremely high temperature occurred during flowering and reduced grain filling percentage and grain yield significantly. 
Figure 3
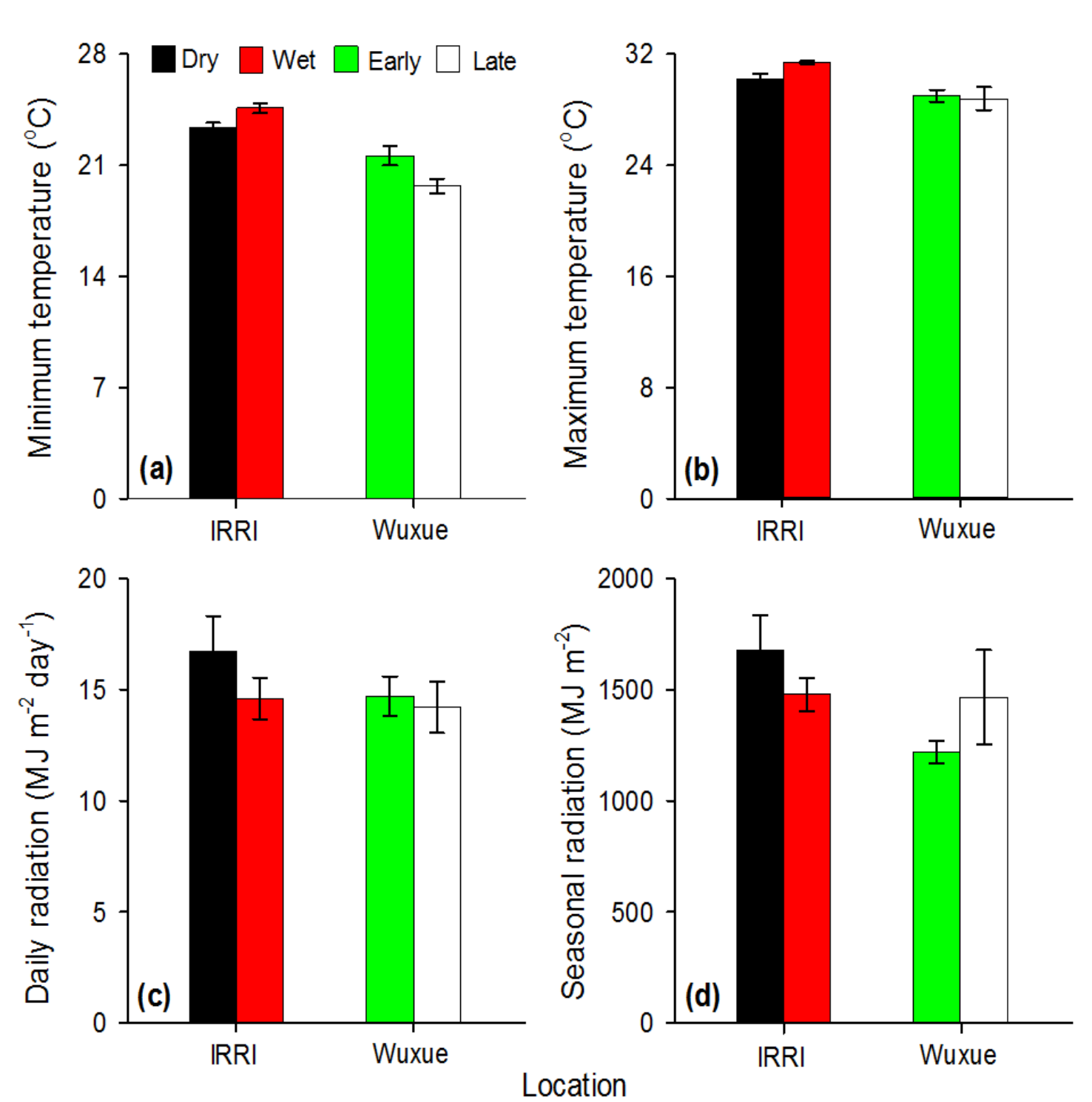

Fig. 3. Average daily minimum temperature (a), average daily maximum temperature (b), average daily solar radiation (c), seasonal solar radiation (d) in the dry and wet seasons at IRRI, and in the early and late seasons at Wuxue. All parameters were calculated from transplanting to maturity. Error bars represent \pm 1 s.d. $(n=3$, standard deviation of three years). 
Figure 4
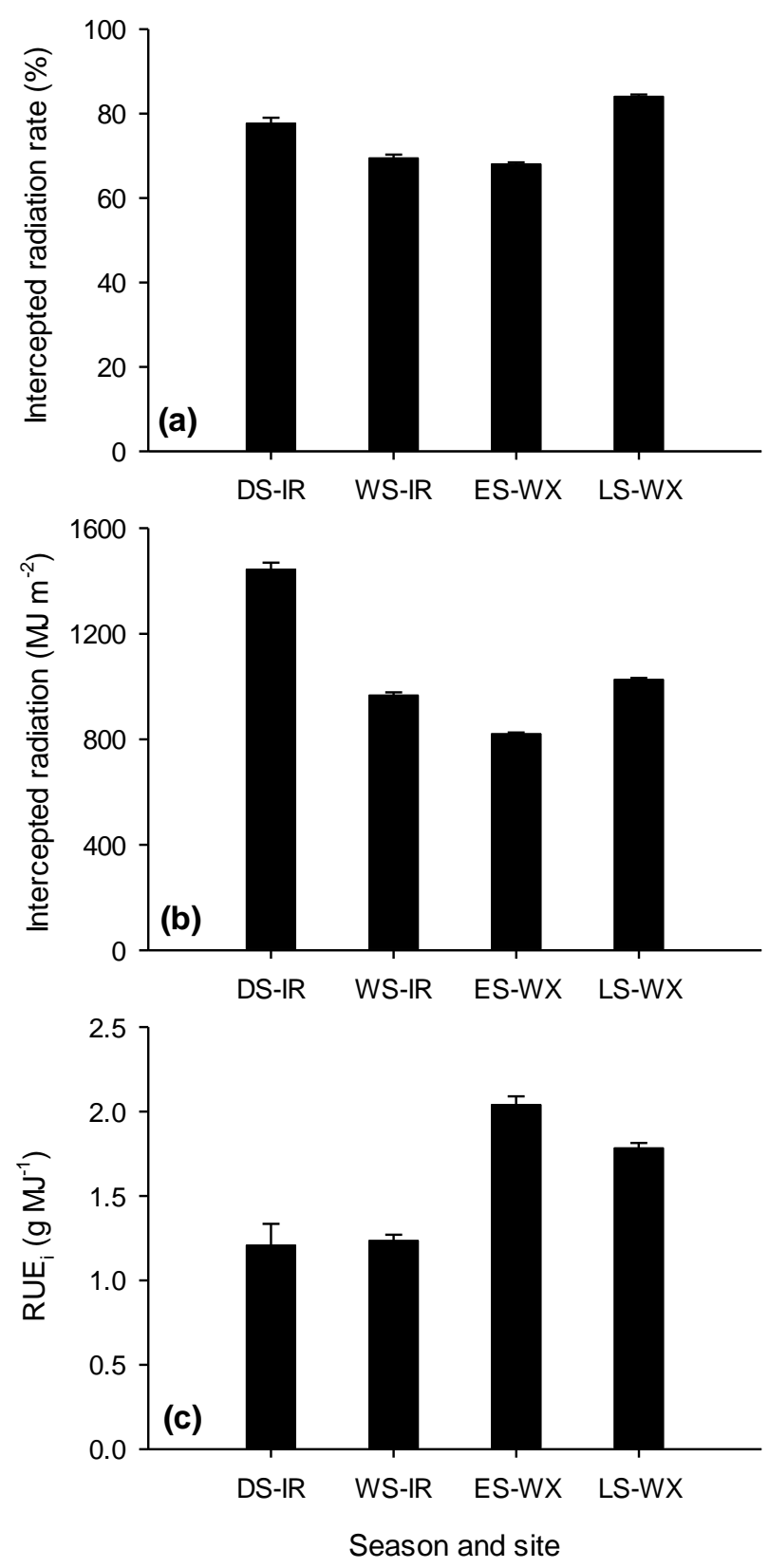

Fig. 4. Intercepted solar radiation rate (a), intercepted solar radiation (b) and intercepted radiation use efficiency $\left(\mathrm{RUE}_{\mathrm{i}}, \mathrm{c}\right)$ in the dry season (DS) of 2010 and wet season (WS) of 2009 at IRRI (IR), and in the early season (ES) and late season (LS) of 2014 at Wuxue (WX). RUE $\mathrm{i}_{\mathrm{i}}$ was calculated as the ratio of aboveground total dry weight production to seasonal intercepted solar radiation from transplanting to maturity. Error bars represent \pm 1 s.d. ( $n=4$, standard deviation of four replications). 
Figure 5
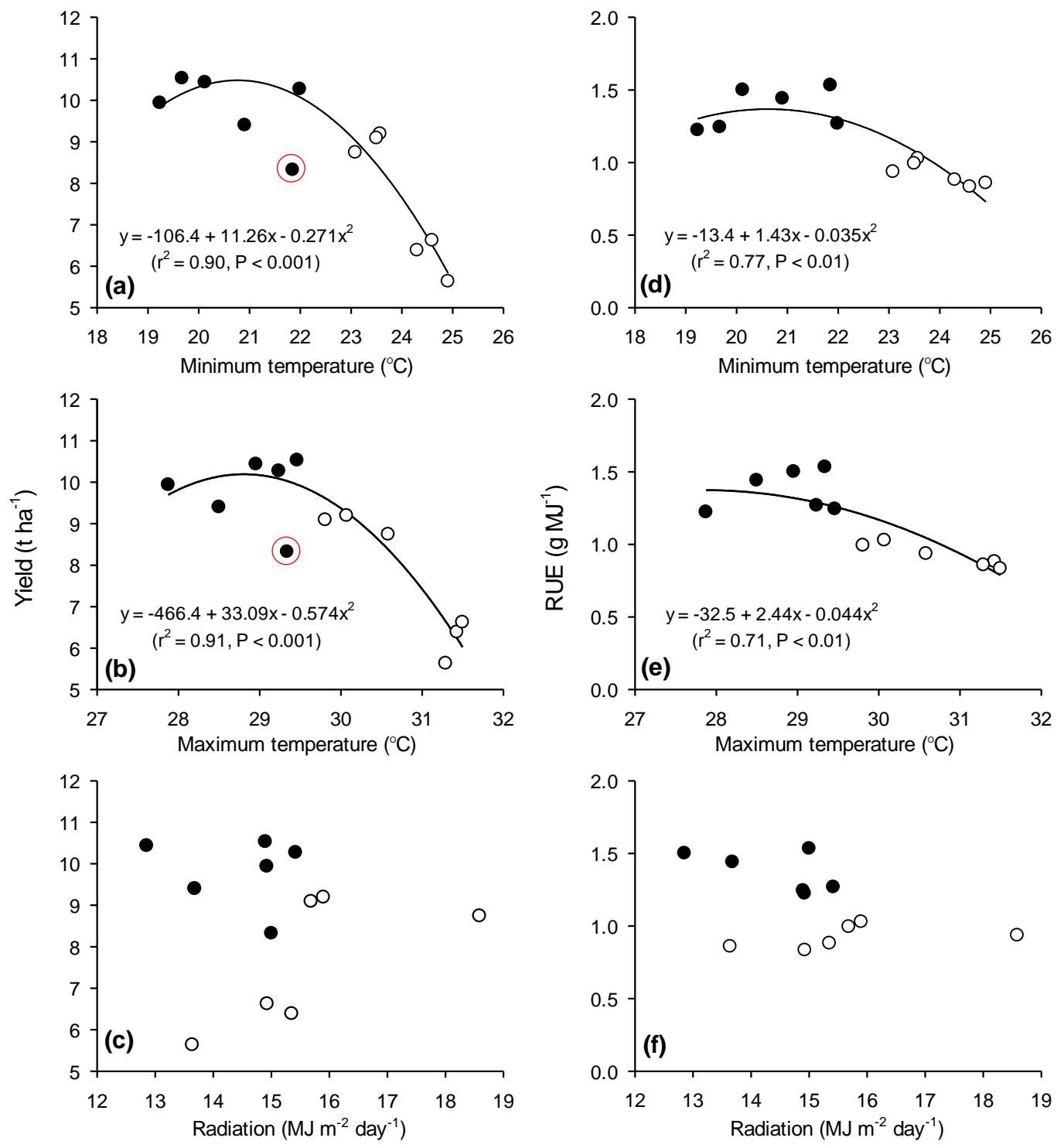

Fig. 5. The relationship of grain yield (a-c) and radiation use efficiency (RUE, d-f) with climate conditions. Open and closed symbols were for IRRI and Wuxue, respectively. Climatic parameters were the averages from transplanting to maturity. Data $(n=12)$ were pooled from experiments conducted in the dry and wet seasons at IRRI in 2008-2010, and in the early and late seasons at Wuxue in 2012-2014. Datum point in circle was an outlier from the early season at Wuxue in 2013 when extremely high temperature occurred during flowering and reduced grain filling percentage and grain yield significantly. 